\title{
PERFORMANCE ALGORITMA GENETIKA (GA) PADA PENJADWALAN MATA PELAJARAN
}

\author{
Eva Desiana, M.Kom \\ Pascasarjana Teknik Informatika Universitas Sumatera Utara, SMP Negeri 5 Pematangsianta \\ Jl. Universitas Medan, Jl. Cornel Simanjuntak Pematangsiantar \\ evadesiana@yahoo.co.id
}

\begin{abstract}
Abstrak - Algoritma Genetika merupakan sebuah algoritma pencarian heuristik yang sangat baik digunakan dalam menyelesaikan masalah optimasi. Pada masalah penjadwalan mata pelajaran algoritma genetika dinilai memiliki performa yang cukup baik dalam menemukan solusi yang optimal. Pemilihan operator dalam algoritma genetika juga sangat menentukan keberhasilan algoritma genetika dalam menemukan solusi yang optimal tersebut. Dalam algoritma genetika evaluasi nilai fitness diperoleh dengan memeriksa setiap gen yang ada pada setiap kromosom induk dengan kriteria penalty sebagai fungsi kelayakannya. Algoritma genetika akan berhenti jika tidak ditemukan crash/bentrok atau sejumlah generasi maksimum telah tercapai. Dari hasil analisis ditemukan bahwa performance dari algoritma genetika cukup baik dalam menyelesaikan masalah penjadwalan mata pelajaran.
\end{abstract}

Keywords - Algoritma genetika, Penjadwalan mata pelajaran..

\section{PENDAHULUAN}

Algoritma Genetika merupakan sebuah algoritma pencarian yang berdasarkan mekanisme seleksi alam dan genetika alam [1]. Algoritma genetika merupakan salah satu algoritma yang sangat baik digunakan untuk menyelesaikan berbagai masalah optimasi dari masalah yang paling sederhana sampai dengan masalah yang sangat rumit sekalipun. Algoritma genetika telah membuktikan efisiensinya dalam menyelesaikan masalah Non-Polynomial [2].

Dalam dunia pendidikan seperti Sekolah Menengah Pertama (SMP) dan Sekolah Menengah Atas (SMA) maupun sederajat setiap awal tahun pelajaran baru selalu membuat jadwal/roster mata pelajaran. Proses penyusunan jadwal mata pelajaran ini sangatlah penting, karena proses belajar mengajar akan berlangsung dengan sangat baik apabila jadwal mata pelajaran tersusun dengan baik. Berbagai faktor yang mempengaruhi dalam penyusunan jadwal mata pelajaran seperti factor guru, ruangan kelas jumlah jam yang tersedia. selama ini penyusunan jadwal mata pelajaran yang telah disusun masih banyak terjadi bentrok antar guru mata pelajaran maupun antar kelas.

\section{A. Rumusan Masalah}

Salah satu kendala yang dialami pihak sekolah dalam penyusunan jadwal mata pelajaran adalah karena terlalu banyak jumlah guru mata pelajaran sementara jumlah kelas atau ruangan terbatas serta pembuatannya masih dilakukan secara manual, hal ini akan sangat menyulitkan bagi pegawai bagian kurikulum. Algoritma Genetika sebagai algoritma pencarian yang heuristik akan dianilisis penerapannya sehingga diharapkan akan dicapai solusi yang optimal dalam penyelesaian masalah penjadwalan mata pelajaran.

\section{B. Batasan Masalah}

Mengingat begitu luasnya ruang lingkup yang berkaitan dengan Algoritma Genetika (GA) oleh karena itu untuk menyajikan hasil penelitian yang efektif dan efisien penulis perlu melakukan pembatasan masalah penelitian yaitu :

1. Algoritma genetika yang diterapkan adalah algoritma genetika dengan menggunakan Roulette Wheel selection pada bagian seleksi dan one point crossover pada bagian persilangan karena lebih sederhana dan mudah untuk diterapkan.

2. Sebagai sampel data yang digunakan pada penelitian ini adalah data penjadwalan pada SMP Negeri 5 Pematangsiantar.

\section{Tujuan Penelitian}

Tujuan dari penulisan penelitian ini adalah untuk menganalisis kinerja dari algoritma genetika dalam menyelesaikan masalah penjadwalan mata pelajaran juga membantu pihak sekolah dalam mempercepat proses penyusunan jadwal mata pelajaran.

\section{LANDASAN TEORI}

\section{A. Algoritma Genetika}

Algoritma genetika merupakan algoritma yang lahir dari sebuah inspirasi teori evolusi Darwin yang mengatakan anggota dari spesies yang lemah lambat laun akan mengalami kepunahan sedangkan anggota dari spesies yang kuat akan tetap dapat bertahan hidup dan berkembang biak untuk kelangsungan hidup spesies tersebut. Algoritma genetika ini di perkenalkan oleh Holland [3] dalam bukunya yang berjudul "Adaptation in natural and artificial system" di Universitas Michigan, Amerika Serikat dan dipopulerkan oleh salah seorang siswanya yang bernama David Goldberg pada tahun 1980-an [4]. 


\section{B. Siklus Algoritma Genetika}

David Golberg adalah orang yang pertama sekali yang memperkenalkan siklus algoritma genetika, dimana siklus ini dimulai dengan membangkitkan sejumlah individu sebagai populasi awal secara random kemudian setiap individu dihitung nilai fitnessnya. Proses selanjutnya adalah dengan menyeleksi individu yang memiliki nilai fitness paling baik. Kromosom-kromosom yang terpilih pada proses seleksi akan dilanjutkan ke proses selanjutnya yaitu proses reproduksi yang dikenal dengan proses crossover, kromosom yang dihasilkan dari proses crossover akan dilanjutkan ke proses berikutnya yaitu proses mutasi. Pada proses mutasi akan dilakukan penggantian gen yang kurang baik dengan gen yang dianggap baik, kromosom yang dihasilkan dari proses mutasi ini nantinya yang akan menjadi generasi baru (offspring), sehingga terbentuklah sebuah populasi baru. Pada setiap generasi, kromosom akan dievaluasi berdasarkan suatu fungsi evaluasi [5]. Populasi baru yang telah dihasilkan akan mengalami siklus yang sama dengan populasi sebelumnya, demikian prosesnya berlangsung secara terus-menerus hingga generasi ke-n yaitu menghasilkan generasi yang sesuai dengan harapan.

\section{Penjadwalan Mata Pelajaran}

Pembuatan jadwal mata pelajaran merupakan salah satu bagian yang paling penting agar terlaksananya proses belajar mengajar dengan baik, efektif dan efisien pada suatu lembaga pendidikan formal. Penjadwalan adalah kegiatan pengalokasian sumbersumber atau mesin-mesin yang ada untuk menjalankan sekumpulan tugas dalam jangka waktu tertentu (Baker, 1974). Penjadwalan juga didefinisikan sebagai rencana pengaturan urutan kerja serta pengalokasian sumber, baik waktu maupun fasilitas untuk setiap operasi yang harus diselesaikan (Vollman, 1998).

Penjadwalan mata pelajaran merupakan proses penyusunan jadwal pelaksanaan yang menginformasikan sejumlah mata pelajaran, guru yang mengajar, ruang, serta waktu kegiatan belajar mengajar. Pada umumnya penyusunan jadwal mata pelajaran dilakukan secara manual, yaitu dengan mencari kolom mana saja yang masih kosong, kemudian menempatkan jadwal pada kolom tersebut. Untuk menyusun jadwal mata pelajaran yang baik.

\section{METODE PENELITIAN}

Metode penelitian merupakan sebuah langkah atau cara yang digunakan dalam melakukan penelitian yang dapat dipertanggung jawabkan hasilnya.

\section{A. Data Yang Digunakan}

Sebagai sampel data yang digunakan pada penelitian ini adalah data penjadwalan pada SMP Negeri 5 Pematangsiantar. Data penjadwalan tersebut meliputi data guru, data mata pelajaran, data hari, data waktu dan data ruangan. Berikut adalah tabel penginputan data :
TABEL I

DATA INPUT

\begin{tabular}{|c|l|l|}
\hline No. & \multicolumn{1}{|c|}{ Data Input } & \multicolumn{1}{c|}{ Jumlah } \\
\hline 1. & Banyaknya Guru & 65 orang \\
\hline 2. & $\begin{array}{l}\text { Banyaknya Mata } \\
\text { Pelajaran }\end{array}$ & Mata Pelajaran \\
\hline 3. & Banyaknya Ruangan & 35 Ruangan \\
\hline 4. & Jumlah alokasi waktu & $\begin{array}{l}7 \text { x pertemuan / } \\
\text { hari }\end{array}$ \\
\hline
\end{tabular}

B. Prosedur Penyelesaian Masalah

Prosedur penyelesaian masalah secara umum pada penelitian ini dapat dilihat pada gambar 6.1 yang ada dibawah ini :

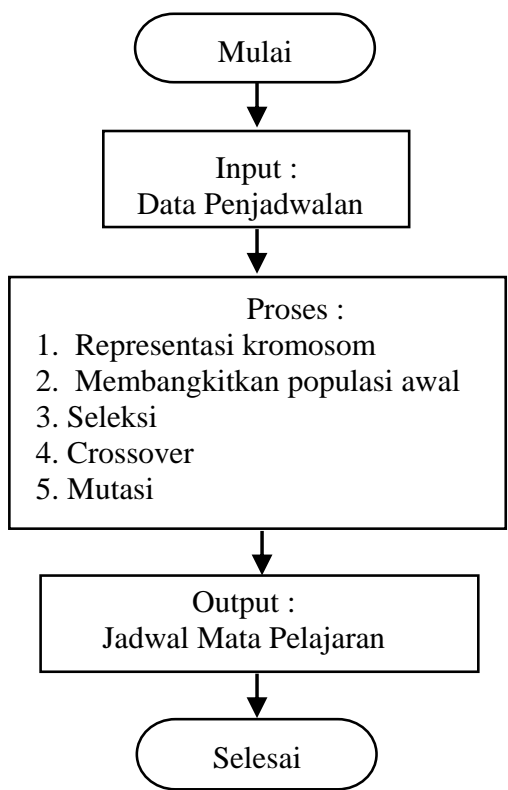

Gbr.1 Prosedur Penyelesaian Masalah

1) Prosedur Representasi Kromosom : proses pengkodean dari penyelesaian suatu masalah, kromosom yang direpresentasikan terdiri dari beberapa gen. Panjang dari kromosom adalah sebanyak gen yang ada yaitu berisi data yang mendukung proses penjadwalan yang telah dilakukan pengkodean terlebih dahulu. pengkodean yang diperlukan dalam penelitian ini adalah pengkodean guru, pengkodean mata pelajaran, durasi per jam pelajaran, pengkodean hari efektif belajar dalam satu minggu, pengkodean jam kegiatan belajar mengajar, dan pengkodean ruangan kelas tempat terjadinya proses belajar mengajar.

Berikut adalah illustrasi pengkodean genetika pada penjadwalan mata pelajaran.

Berikut adalah tabel kode data guru:

TABEL II

KODE DATA GURU

\begin{tabular}{|c|c|}
\multicolumn{2}{|c|}{ KODE DATA GURU } \\
\hline Kode Guru & Nama Guru \\
\hline 1 & BR \\
\hline 2 & TR \\
\hline 3 & EH \\
\hline 4 & RI \\
\hline 5 & SO \\
\hline 6 & NM \\
\hline
\end{tabular}




\begin{tabular}{|c|c|}
\hline$\ldots$ & $\ldots$ \\
\hline 60 & EV \\
\hline 61 & AB \\
\hline 62 & RS \\
\hline 63 & AK \\
\hline 64 & YM \\
\hline 65 & MO \\
\hline
\end{tabular}

Berikut adalah tabel kode mata pelajaran :

TABEL III

KODE MATA PELAJARAN

\begin{tabular}{|c|l|}
\hline $\begin{array}{c}\text { Kode } \\
\text { Mata pelajaran }\end{array}$ & \multicolumn{1}{|c|}{ Mata Pelajaran } \\
\hline 1 & Pendidikan Agama Kristen \\
\hline 2 & Pendidikan Agama Islam \\
\hline 3 & Pendidikan Agama Khatolik \\
\hline 4 & PKn \\
\hline 5 & Bahasa Indonesia \\
\hline 6 & Bahasa Inggris \\
\hline 7 & Matematika \\
\hline 8 & IPA \\
\hline 9 & IPS \\
\hline 10 & Seni Budaya \\
\hline 11 & PENJAS ORKES \\
\hline 12 & Keterampilan \\
\hline 13 & TIK \\
\hline 14 & BK \\
\hline & \\
\hline
\end{tabular}

Berikut adalah tabel kode hari efektif :

TABEL IV KODE HARI

\begin{tabular}{|c|l|}
\hline Kode Hari & \multicolumn{1}{|c|}{ Hari } \\
\hline 1 & Senin \\
\hline 2 & Selasa \\
\hline 3 & Rabu \\
\hline 4 & Kamis \\
\hline 5 & Jum'at \\
\hline 6 & Sabtu \\
\hline
\end{tabular}

Berikut adalah tabel kode ruangan kelas :

TABEL V KODE RUANGAN

\begin{tabular}{|c|c|}
\hline Kode Ruangan & Ruangan \\
\hline 1 & VII-1 \\
\hline 2 & VII-2 \\
\hline$\ldots$ & $\ldots$ \\
\hline 12 & VII-12 \\
\hline 13 & VIII-1 \\
\hline 14 & VIII-2 \\
\hline$\ldots$ & $\ldots$ \\
\hline 24 & VIII-12 \\
\hline 25 & IX-1 \\
\hline 26 & IX-2 \\
\hline$\ldots$ & $\ldots$ \\
\hline 35 & IX-11 \\
\hline
\end{tabular}

2) Populasi awal : dibuat dengan membangkitkan individu sebanyak jumlah populasi yang telah ditentukan sebelumnya. Kromosom dibangkitkan sebanyak jumlah solusi yaitu sebanyak jumlah guru sebanyak 65 buah kromosom. Bangkitkan gen untuk masing-masing kromosom dengan jumlah gen sebanyak 6 buah gen yang terdiri dari gen guru, gen mata pelajaran, gen durasi, gen hari, gen jam, dan gen ruangan.

TABEL VI

POPULASI AWAL

\begin{tabular}{|c|l|l|l|l|}
\hline Krd & \multicolumn{1}{|c|}{ Individu } & \multicolumn{1}{|c|}{ Individu } & \multicolumn{1}{|c|}{ Individu } & \multicolumn{1}{|c|}{ Individu } \\
\hline 1 & 1 & \multicolumn{1}{|c|}{2} & \multicolumn{1}{|c|}{3} & \multicolumn{1}{c|}{4} \\
\hline 2 & $2,1,2,2,1,3$ & $1,1,2,5,7,35$ & $1,1,2,1,3,5$ & $1,1,2,2,2,11$ \\
3 & $3,1,2,4,3,10$ & $2,1,2,2,6,8$ & $2,1,2,4,1,6$ & $2,1,2,5,5,14$ \\
4 & $4,2,2,1,3,3$ & $4,2,2,6,6,4$ & $4,2,2,4,2,13$ & $4,2,2,5,3,14$ \\
5 & $5,3,2,1,1,12$ & $5,3,2,2,3,9$ & $5,3,2,3,2,7$ & $5,3,2,4,5,8$ \\
.. &.. &.. &.. &.. \\
65 & $65,14,1,3,4,2$ & $65,14,1,2,5,3$ & $65,14,1,6,7,3,1$ & $65,14,1,5,7,2$ \\
& & & & \\
\hline
\end{tabular}

3) Evaluasi Nilai fitness : Individu-individu dalam populasi telah terbentuk, langkah selanjutnya akan menghitung nilai fitness dari setiap individu yang ada. Fitness akan dihitung berdasarkan jumlah pelanggaran atau penalty yang terjadi pada setiap slot kromosom dalam suatu individu. Dalam metode penalty solusi tak layak yang dihasilkan tetap digunakan akan tetapi diberi penalty.

Berikut adalah aturan penghitungan fungsi fitness (Ross et al. 2006).

$$
f(g)=\frac{1}{\left(1+\sum P i v i(g)\right)}
$$

dimana :

$f(g)$ adalah fungsi fitness.

$P i$ adalah penalty yang diberikan untuk aturan $i$. $v i(g)=1$ jika jadwal $g$ melanggar aturan $\mathrm{i}$, bernilai 0 jika sebaliknya.

TABEL VII ATURAN PENALTY

\begin{tabular}{|c|c|c|}
\hline $\begin{array}{c}\text { Constr } \\
\text { ain }\end{array}$ & \multicolumn{1}{|c|}{ Keterangan } & $\begin{array}{c}\text { Nilai } \\
\text { Penalty }\end{array}$ \\
\hline 1. & $\begin{array}{l}\text { - Hari Senin Jam ke-1 UPB. } \\
\text { - Hari Jum'at sampai Jam ke-5. } \\
\text { - Hari sabtu sampai Jam Ke-6. }\end{array}$ & 1 \\
\hline 2. & -1 Kelas hanya diajarkan & 1 \\
\hline 3. & $\begin{array}{l}\text { Satu orang guru masuk di } \\
\text { hari dan jam yang sama } \\
\text { tetapi ruangan berbeda. } \\
\text { Dua orang guru masuk di } \\
\text { hari, jam dan ruangan yang } \\
\text { sama. }\end{array}$ & 1 \\
\hline \multicolumn{2}{|c}{} \\
\hline
\end{tabular}


4) Proses Seleksi : Pada penelitian ini metode yang digunakan adalah seleksi roda rolet (roulette wheel selection). Pada seleksi ini individu dipilih berdasarkan nilai fitness mereka untuk memilih individu mana yang akan mengalami proses perkawinan atau pindah silang, lebih baik kualitas suatu individu akan lebih besar peluangnya untuk terpilih. Pada proses roulette wheel selection ini akan dihitung nilai kumulatif dari probabilitas fitness masing-masing individu.

$$
\mathrm{P}(\mathrm{i})=\frac{f i}{\sum f j}
$$$$
j=1
$$

Dimana : $\mathrm{P}(\mathrm{i})=$ Probabilitas fitness ke-i $f i=$ Nilai fitness individu ke-i

5) Proses Crossover : Pada penelitian ini metode crossover yang digunakan adalah one point crossover. Pada metode crossover ini tidak semua induk akan mengalami proses crossover karena pemilihan induk melibatkan parameter probabilitas crossover $(\mathrm{Pc})$. Individu ke-i dinyatakan terpilih sebagai induk pada proses crossover jika memiliki nilai fitness terbaik.

Misalkan Probabilitas crossover adalah sebesar 70\%, maka diperoleh probabilitas crossover sesuai dengan persamaan berikut :

$$
\begin{aligned}
& \mathrm{Pc}=\mathrm{Jlh} \% \times \text { banyaknya individu yang ada } \\
& \mathrm{Pc}=70 \% \times 4 \\
& \mathrm{Pc}=2,8
\end{aligned}
$$

Pada persamaan diatas diperoleh 2 individu yang akan di kenai proses crossover yaitu individu yang memiliki nilai fitness paling baik. Setelah proses seleksi maka diperoleh individu yang akan dicrossover adalah individu ke-1 dan individu ke-3.

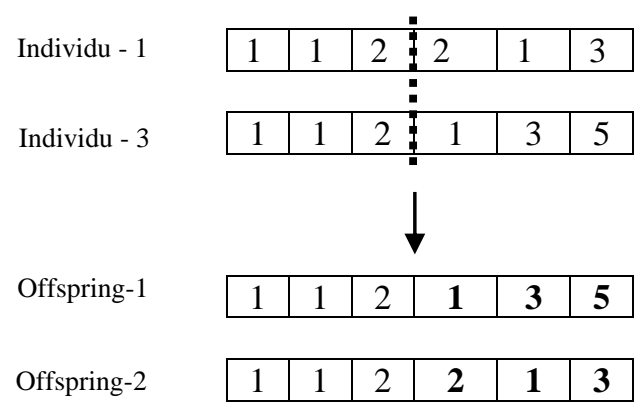

Gbr.2 Illustrasi proses one point crossover

6) Proses Mutasi : Mutasi merupakan operator dalam algoritma genetika yang bertujuan untuk mengubah gen-gen tertentu yang terdapat dalam sebuah kromosom. Pada penelitian ini proses mutasi yang digunakan adalah skema swap mutation.
Jumlah kromosom yang mengalami mutasi dalam satu populasi ditentukan oleh parameter probabilitas mutasi. Proses mutasi sebagai berikut :

1. Hitung jumlah gen yang ada dalam populasi

$\mathrm{Jlh}$ gen $=\mathrm{Jlh}$ ind. $*$ Banyak gen dalam ind.

$$
=65 * 6=390
$$

2. Hitung Jumlah gen yang akan mengalami mutasi dengan parameter probabilitas mutasi yang telah ditentukan sebelumnya, misalnya $P m$ kita tentukan $10 \%$, maka :

$\mathrm{Pm}=$ Jumlah $\% *$ Jumlah gen

\begin{tabular}{|c|c|c|c|c|c|c|}
\hline Dffspring-1 & 1 & 1 & 2 & 1 & 3 & 5 \\
\hline $\mathrm{ffspr}$ & 1 & 1 & 2 & 2 & 1 & 3 \\
\hline
\end{tabular}

$$
=10 \% * 390=39(\mathrm{Jlh} \text { gen yang dimutasi })
$$

Kromosom sebelum mutasi hasil dari crossover.

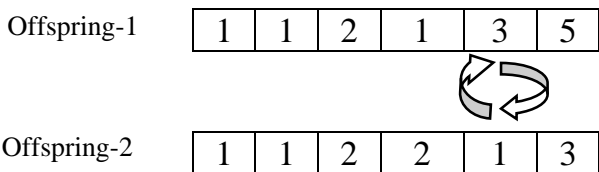

Kromosom setelah mutasi

\section{HASIL DAN PEMBAHASAN}

\section{A. Parameter Yang Digunakan}

Pada pengujian ini penulis menggunakan beberapa parameter yang akan diterapkan pada proses algoritma genetika. Parameter pengujian dapat dilihat pada tabel berikut di bawah ini:

TABEL VIII PARAMETER PENGUJIAN

\begin{tabular}{|l|c|}
\hline Nama Parameter & Nilai \\
\hline Jumlah Individu & 50 \\
\hline Probabilitas Crossover & 0.7 \\
\hline Probabilitas Mutasi & 0.1 \\
\hline Generasi & 100 \\
\hline
\end{tabular}

Pengujian dilakukan untuk 100 generasi, 50 individu, probabilitas crossover 0.7 dan probabilitas mutasi sebesar 0.1. Hasil pengujian disajikan pada tabel 7.2 yang ada di bawah ini.

\begin{tabular}{|c|c|l|}
\multicolumn{3}{c}{ TABEL IX } \\
\multicolumn{1}{c}{ HASIL PENGUJIAN } \\
\hline Generasi & Total Crash & Nilai Best Fitness \\
\hline 10 & 4 & 0,2 \\
\hline 20 & 5 & 0,166666667 \\
\hline 30 & 3 & 0,25 \\
\hline 40 & 6 & 0,142857143 \\
\hline 50 & 6 & 0,142857143 \\
\hline 60 & 6 & 0,142857143 \\
\hline 70 & 5 & 0,166666667 \\
\hline 80 & 2 & 0,333333333 \\
\hline
\end{tabular}




\begin{tabular}{|c|c|l|}
\hline 90 & 4 & 0,2 \\
\hline 100 & 4 & 0,2 \\
\hline Rata-rata & 4,5 & 0,19452381 \\
\hline
\end{tabular}

Pada tabel IX hasil pengujian dengan parameter 100 generasi, 50 individu, $\mathrm{Pc}=0.7$ dan $\mathrm{Pm}=0.1$ maka diperoleh nilai best fitness pada generasi ke-80 adalah 0,33 dengan total $\mathrm{crash} /$ bentrok $=2$.

Berdasarkan dari Tabel IX di atas dapat disimpulkan bahwa semakin banyak jumlah individu yang diterapkan akan semakin baik hasil yang akan diperoleh. Pada kasus penjadwalan mata pelajaran ini dengan menerapkan algoritma genetika menggunakan parameter dengan jumlah generasi sebanyak 100 generasi, jumlah individu sebanyak 50 individu, probabilitas crossover sebesar 0.7 dan nilai probabilitas mutasi sebesar 0.1. Dari hasil pengujian yang dilakukan kinerja dari algoritma genetika terlihat cukup baik dimana pada generasi ke-80 ditemukan hanya 2 total crash/ bentrok yang memiliki nilai best fitness sebesar 0,19452381.

\section{KESIMPULAN}

Berdasarkan dari hasil dan pembahasan yang ada, maka kesimpulan yang dapat diperoleh dari penelitian ini adalah sebagai berikut :

1. Penerapan algoritma genetika pada penjadwalan mata pelajaran memiliki performa yang cukup baik.

2. Keberhasilan penerapan algoritma genetika dalam mencapai global optimum sangat di pengaruhi oleh beberapa nilai parameter yang diterapkan.

3. Semakin banyak jumlah individu yang dibangkitkan maka akan semakin sedikit jumlah crash/bentrok yang terjadi maka solusi yang dihasilkan akan semakin lebih baik.

\section{REFERENSI}

[1] Goldberg, D. E. 1989. Genetic Algorithms in Search, Optimization, and Machine Learning. United State of America : Addison-Westley.

[2] Davis, 1991, Handbook of Genetic Algorithms, New York : Van Nostrand Reinhold.

[3] Holland, J. H. 1975. Adaptation in Natural and Artificial Systems, Ann Arbor, MI, University of Michigan press.

[4] Haupt, R. L. \& Haupt. 2004. Practical Genetic Algorithmns. New Yersey: Jhon Wiley dan Sons,Inc.

[5] Goldberg, D. E. \& Richardson, J. 1997. Genetic algorithms with sharing for multimodal function optimization, Proceedings of the $2^{\text {nd }}$ International Conference on Genetic algorithms and their application: pp. $41-49$. 